\title{
Quality Assessment of Municipal Solid Waste Compost
}

\author{
M. M. Rahmana, M.S.H. Bhuiyan ${ }^{b}$, M.A. Roufb, R.R. Sarkerb, M. H. Rashid ${ }^{b *}$ \\ a Department of Soil Science, Bangladesh Agricultural University, Mymensingh, Bangladesh \\ b Bangladesh Institute of Nuclear Agriculture, Mymensingh, Bangladesh \\ ${ }^{*}$ Corresponding Author e-mail: mhrashid08@gmail.com
}

\section{DOI: 10.2478/acmy-2020-0006}

\begin{abstract}
:
There are more than 522 towns and cities in Bangladesh, which generate thousands of tons of solid waste known as Municipal Solid Waste. Low collection coverage and disposal facilities are responsible for unsatisfactory waste management. The composting technology is a good alternative method for managing MSW. The present study was conducted to assess the quality of the MSW compost produced from the solid wastes of Mymensingh Pourashava. For quality assessment physical, chemical and biological properties of prepared compost namelye bulk density, porosity, water-holding capacity, moisture content, $\mathrm{pH}$, organic matter content, C:N ratio, NPKS content, buffering capacity, soluble salts content, heavy metal content and the presence of harmful organisms in the MSW compost were studied. The results indicated that the MSW compost was matured and stable having pH 7.3 and buffering capacity of the MSW compost were good but the organic matter content and C : N (14.5) ratio were low. The N, P, K and S content of the MSW compost were 0.9, 0.3, 0.4 and 0.45 percent of the total volume. The soluble salts content and heavy metal content of the compost were found to be within the permissible limits. The MSW compost contained no E. coli and Salmonella. From the results, it can be concluded that, the composting could produce acceptable quality of compost, which can be used as fertilizer or soil amendment.
\end{abstract}

Keywords: MSW compost, Maturity test, Physico-chemical characteristics, Heavy metals and quality assessment.

\subsection{Introduction:}

The solid waste generated mainly consists of food waste, paper, polyethylene, cloth, rags, garden trimmings, construction debris, wood, leaves and branches, ferrous/ non-ferrous metal, glass, shredded skins and leather, hospital waste, slag, animal waste, industrial waste, old appliances, and miscellaneous waste. The waste generation rate of Bangladesh is $0.5 \mathrm{~kg} /$ capita/day [1]. A large amount of municipal solid wastes are generated daily in Dhaka. Dhaka Metropolitan area generated more than 5000 tons per day or 1.96 million tons per annum in 2002-03. The waste generation was to grow at the rate of $5.6 \%$ each year. By 2021, the daily waste generation in Dhaka will amount to 15.1 thousand tons and annual generation will be 5.52 million tons [2].

The total waste generation of Dhaka ,Chittagong, Khulna, Rajshahi, Barisal and Sylhet city corporation are 5340, 1315, 520, 170, 130 and 215 tons/day respectively [3]. The Dhaka city contributed the major portion as measured as 5340 tons/day which is the $69 \%$ of total waste generated in the six cities. The generation rates were ranged from 0.325 to $0.485 \mathrm{~kg} / \mathrm{cap} /$ day, while the highest generation rate in Dhaka, lowest in Barisal and the average was 0.387 $\mathrm{kg} / \mathrm{capita} /$ day for six major cities [3]. Amount of daily waste generation of Mymensingh municipal is about 100 tons [4].

Municipal solid waste comprises all the wastes arising from human and animal activities. Considering rapid expansion of the cities/towns with massive migration of population from rural to urban centers, as well as considerable increases in per capita generation of wastes with each passing day, generation of MSW has continuously been increasing. Majority (more than 90\%) of these wastes are used for unscientific land filling or uncontrolled dumping on outskirts of towns and cities, which have serious environmental implications in global warming (by green-house gases emission) [5,6]. In the tropical countries like Bangladesh, the major portion of the total solid waste is biodegradable organic matter. The high content of these biodegradable organic matter and other inert material, results in high waste density and high moisture content. Theses physical characteristics significantly influence the feasibility of certain treatment options. Wastes with a high water or inert content will have low calorific value and thus may not be suitable for incineration [7-9].

However, composting technology seems to be a good alternative method for managing MSW. Composting MSW is a method of diverting organic waste materials from landfills and creating a product that is suitable for agricultural purposes, decreases the use of commercial fertilizers, increases the capacity for household waste recycling and improves the quality of the soil [10-14]. Composting MSW reduces the volume of the waste, kills pathogens that may be present, decreases germination of weeds in agricultural fields and destroys malodorous compounds [15]. A major concern associated with the use of MSW compost remains the presence of heavy metals that can be toxic to plants, enter the food chain, contaminate water, and affect human health. The presence of heavy metals in MSW composts can affect some microbiological characteristics of soil such as the structure of the soil micro-biota, which are responsible for the transformations making nutrients available to plants. MSW compost prepared from the solid organic materials inevitably contains some heavy metals like boron, zinc, copper, nickel, arsenic, cadmium, lead and mercury. The impact of metals on plants grown in compost amended soils depends not only on the concentration of metals, but also on soil properties such as $\mathrm{pH}$, organic matter content and CEC.

Soils that have been cropped for many years may be deficient in nutrients such as boron, zinc and copper, and MSW compost could mitigate such deficiencies [16]. There has been a recent resurgence of interest in the municipal solid waste compost as other options for solid waste disposal such as land filling and incineration become less publicly acceptable and increasingly costly. Composting is defined as the aerobic biological decomposition and stabilization of organic substrates, under conditions that allow development of thermophilic temperature as a result of biologically produced heat. Compost prepared from different organic wastes differ in their quality and stability, which further depends upon the composition of raw material used for the compost production [17]. Therefore the prime objective of this study was quality assessment of MSW compost using municipal waste of Mymensingh pourashava.

\subsection{Materials and Methods}

Municipal solid wastes were collected from the city area of Mymensingh and brought to the field laboratory of the Department of Soil Science of Bangladesh Agricultural University, Mymensingh. Then the wastes were spread out, separated for degradable and non degradable parts and their weights were recorded. The non degradable materials were not used for composting.

\subsection{Compost preparation}

The composting materials were chopped into small pieces, mixed well and then the materials were placed into the compost pits. Each composting pit consist of 6 to 7 successive layers of composting materials. The thickness of each layer was 7-8 inches. A thin layer of soil and decomposed cow dung and small amount of urea were added in between two consecutive layers of composting materials to enhance the composting rate. After piling, the compost pits were covered with a layer of banana leaves to reduce moisture loss. The compost piles were turned after 15 days interval up to 90 days of composting. The finished compost samples were collected and the transported in sealed polythine to the laboratory of the department of Soil Science, BAU, Mymensingh, oven dried at $70^{\circ} \mathrm{C}$ and the compost is homogenized through a $2 \mathrm{~mm}$ sieve. The compost samples were stored in the dark bottles till further analysis. 


\subsection{Compost maturity test}

Compost maturity test included phytotoxicity test, colour test, jar test, germination test, respiration test and self-heating test. The tests were measured following the methods described [18].

\subsection{Phytotoxicity bioassay}

A pot experiment was conducted in the net house of the Dept. of Soil Science, BAU Mymensingh to determine whether compost contains substances that inhibit seed germination or growth of the radical. Fast growing radish seeds were used as test crop. Then the rate of germination and length of radical of the seedlings in compost were calculated carefully.

\subsection{Compost color or Bag test}

A handful of compost sample was taken from the inside of the pile and was moistened it well. The compost was put in a plastic bag and it was sealed. The bag sealed was kept at room temperature for five to seven days. Then the bag was opened and smelt the contents. It should have a pleasant, earthy, soillike smell; it is stable enough to be cured. If it smells is foul or rotten or a bit like ammonia, the compost is not completely finished, the composting process should be continued.

\subsection{Germination Test/ Plant germination in compost}

For the germination test, two containers were filled with moist compost and two containers were filled with moist soil. Eight radish seeds were sawn each of the four containers. The containers were covered with plastic wrap to keep the containers moist. After five to seven days, the number of seedlings in each container is counted. If the compost germination rate and speed are significantly less than that of the plain soil, the compost is not yet mature and needs to continue composting or curing.

\subsection{Jar test or Sniff test}

It was done by visiting the compost site or getting a sample from the compost pit and was checked for foul odors. Foul smelling compost is not be stable and should not be used.

\subsection{Respiration test (based on $\mathrm{CO}_{2}$ production)}

Compost stability was measured by $\mathrm{CO}_{2}$ evolution and trapping (in $\mathrm{NaOH}$ ) method, where samples was incubated for 3 days at $50 \%$ moisture level (preincubation) and subsequently $\mathrm{CO}_{2}$ evolution was measured daily in air-sealed flasks for 7 days. Average of 7 days measurement is taken as a measure of compost stability. The microbes present in the compost produce $\mathrm{CO}_{2}$ which was absorbed by $\mathrm{NaOH}$ trap placed beside the compost jar in the air tight plastic pot. This was accomplished by titrating with $1 \mathrm{M} \mathrm{HCl} \mathrm{according} \mathrm{to} \mathrm{the} \mathrm{procedure:}$

CO2.C (mg)= HCl(b)-HCl(s)/1000ml/L x $\{\mathrm{HCl}$ molarity (mol/L) x $1000 \mathrm{ml} / \mathrm{L} \times 12 \mathrm{~g} \mathrm{C} / \mathrm{mol} \times 1000 \mathrm{mg} / \mathrm{g}\}$

Where:

$\mathrm{HCl} b=\mathrm{ml} \mathrm{HCl}$ used in the titration of blank

$\mathrm{HCl} \mathrm{s}=\mathrm{ml} \mathrm{HCl}$ used in the titration of sample (from jar containing compost)

CO2. $\mathrm{C}=$ mass of $\mathrm{CO} 2$ - carbon generated $(\mathrm{mg})$

Which can be simplifies to :

C02. C $(\mathrm{mg})=(\mathrm{HCl} b-\mathrm{HCls}) \times 12$

Organic C $(\mathrm{g})=($ Wet wt of sample) $(100-\%$ moisture $) \% \mathrm{C}$

$=25 \mathrm{~g} \times 50 \% \times \% \mathrm{C}$

$=12.5 \times \% \mathrm{C} \quad[\% \mathrm{C}=\% \mathrm{OM} / 1.73]$

$\mathrm{mg} \mathrm{CO} 2 . \mathrm{C} / \mathrm{g}$ organic carbon /day

$=$ mass of $\mathrm{CO} 2 \cdot \mathrm{C}(\mathrm{mg} /$ day $) /$ organic carbon $(\mathrm{g})$

\subsection{Self-heating test (based on heat production by microorganisms)}

This method is simple but costly because it requires a Dewar flask. With the flask, various levels of compost stability can determined, from fresh to very mature compost. A sample of compost was added to the flask and monitored for the highest rise in temperature. Higher rises in temperature indicate less mature compost.

\subsection{Physico-chemical analysis}

The collected compost samples were analyzed for various physico-chemical characteristics such as Moisture content (drying at $1050 \mathrm{C}$ to constant weight by gravimetric method); Particle and Bulk densities (Pycnometric method); porosity, water-holding capacity, pH (1:5 water extract by pH meter); Electrical conductivity (1:5 water extract, conductivity meter); buffering capacity were measured following the methods described [19]. Total organic carbon (wet oxidation with potassium dichromate Walkey and Black method ); Organic matter (ashing; loss of ignition method); Total organic nitrogen (Kjeldhal method); Phosphorus (tri acid mixture with a aqua digestion); potassium and sodium (1N ammonium acetate extract using flame photometer method), Soluble sulphate (1:5 water extract for $\mathrm{BaCl}_{2}$ method); The organic matter content, $\mathrm{C}: \mathrm{N}$ ratio, $\mathrm{N}, \mathrm{P}, \mathrm{K}$ and $\mathrm{S}$ content and soluble salts of the MSW compost were analyzed following the methods described [20-22].

\subsection{Heavy metal analysis}

The $1 \mathrm{~g}$ of oven dried sample was transferred to $100 \mathrm{ml}$ beaker. A tri acid mixture (10 ml) consisting of HNO3, H2SO4 and HClO4 in the ratio 9:2:1 was added to each of the flasks with $100 \mathrm{ml}$ of distilled water and digested on hot plate until the dense fumes of HClO4 cease, to get a clear extract. The beakers were then allowed to cool and the extracts were filtered with Whatman No.42 filter paper. The filtrates were diluted to $100 \mathrm{ml}$ in standard flasks to have an adequate volume of solution for analysis. The dilution factor was noted. The water soluble and acid digested extracts were analyzed for quantitative estimation of heavy metals (copper, cadmium, lead, mercury and arsenic) using atomic absorption spectrophotometer [23].

\subsection{Bacteriological analysis}

The samples were collected in sterilized polythene bags for biological analysis and the media used for the bacteriological analysis of compost includes Nutrient Agar (NA), Lactose Broth (LB) and Eosin Methylene Blue agar (EMB). All the media used were weighed and prepared acco rding to the manufactures specification, with respect to the given instructions and directions. $1 \mathrm{~g}$ of each compost samples was suspended into $10 \mathrm{ml}$ of sterile saline solution and 
serial diluted further up to $10^{-4}$ dilution aseptically. $0.1 \mathrm{ml}$ of each diluted compost suspension was poured onto nutrient agar plate using spread plate technique. Plates were incubated for $24 \mathrm{hr}$ at $37^{\circ} \mathrm{C}$ and bacterial colonies are isolates and further pure culture were subjected to determine the identity of the bacteria isolates with reference to practical microbiology $[24,25]$.

\subsection{Results and Discussion}

\subsection{Composition of municipal solid wastes}

The composition of the solid wastes collected from the Mymensingh Paurashava has been shown in the Table 1. The Mymensingh municipal solid wastes contained $60 \%$ degradable and $40 \%$ non-degradable materials. The degradable materials included kitchen waste, market waste, leaves, grasses, twigs, paper, clothes, cotton, gunny bag, woods, saw dust, slaughterhouse and some others wastes. Among the degradable material 14\% was various market waste where kitchen waste was $12 \%$. The non-degradable group contains polythene, plastic, rubber, nylon, stones, bricks, glass, metals, battery, syringe, medicine containers, bone, hair and others.

Table1: Composition of Mymensingh municipal solid waste

\begin{tabular}{|l|l|l|l|}
\hline Sr. no. & Component of MSW & $\begin{array}{l}\text { Composition } \\
(\mathbf{\%})\end{array}$ & $\begin{array}{l}\text { Composition } \\
(\mathbf{k g} / \text { ton) }\end{array}$ \\
\hline & Organic/ degradable materials & & \\
\hline 1 & Kitchen waste & 12 & 120 \\
\hline 2 & Market, & 14 & 140 \\
\hline 3 & Leaves, weed,grass .. & 11 & 110 \\
\hline 4 & paper & 3 & 30 \\
\hline 5 & Cloths, cotton, gunny bags.. & 2 & 20 \\
\hline 6 & Slaughter house waste & 6 & 60 \\
\hline 7 & Wooden matter, saw dust & 4 & 40 \\
\hline 8 & Others & 8 & 80 \\
\hline & Total & $\mathbf{6 0}$ & $\mathbf{6 0 0}$ \\
\hline & In organic/Non degradable & \\
\hline 1 & Polythene, plastic, rubber, nylon. & 10 & 100 \\
\hline 2 & Rocks, stones, bricks, glass, sand, metal. & 15 \\
\hline 3 & Battery, syringe, medicine cover, bottom . & 15 \\
\hline 4 & Bone, teeth, hair, seeds, fibers & 7 & 70 \\
\hline 5 & Others & 4 & 40 \\
\hline & Total & 4 & 40 \\
\hline
\end{tabular}

The composition of municipal solid waste varies greatly with seasons and places, and also changes significantly with time. In summer various kinds of fruits are available in market resulting a high moisture and nutrient content in the solid wastes. On the other hand, composition of MSW collected from residential and commercial places differ widely. Thus, waste quantities as well as composition are inextricably linked to the vibrancy of economic activity and resource consumption pattern of the society which generates the waste.

\subsection{Maturity of MSW compost}

The observations and results of the maturity tests have been presented in the Table 2. In Phytotoxicity bioassay test seedlings are grown in a water extract of compost, provides a means of measuring the combined toxicity of whatever contaminants may be present. Normal seedling growth was observed in the present study. Immature compost may contain methane, ammonia, or acetic acid that are detrimental to plant growth. Jar test indicates the stage of organic matter decomposition based on odor development in an enclosed sample. Earthy odor greeting from the compost after the Jar test confirmed the maturity and stability of the compost. Undecomposed compost smells rotten after being moistened and enclosed for a few days because of development of noxious compounds such as methane or organic acids under anaerobic condition.

Table.2: Compost maturity test

\begin{tabular}{|l|l|l|}
\hline Sl.No. & Tests & Observations/results \\
\hline 1 & Jar test & Earthy odour was greeted. \\
\hline 2 & Respiration test & $\mathrm{CO}_{2}$ production rate was less than $1.23 \mathrm{mg} / \mathrm{g} /$ day. \\
\hline 4 & Phytotoxicity test & Normal seedling growth was observed. \\
\hline 5 & Colour test & Brown colour was found \\
\hline 6 & Bag test & Stable temperature was found \\
\hline
\end{tabular}

Respiration test also indicates the stage of organic waste decomposition based on $\mathrm{CO}_{2}$ production. Both heat and $\mathrm{CO}_{2}$ are released by microbes as they decompose organic matter. The result showed the low $\mathrm{CO}_{2}$ production rate of the compost of $1.23 \mathrm{mg} / \mathrm{g} /$ day indicated the maturity of the compost. The colour of the compost was dark brown when moist and became lighter when dried. It looked brown and crumby, and no recognizable traces of the initial ingredients were observed. Self-heating test result showed that the stable temperature indicated the maturity of the compost.

\subsection{Physical properties of MSW compost}

The physical characteristics of the MSW compost have been presented in the Table 3 . The moisture content (25\%), water-holding capacity (840mg kg-1), bulk density $(0.58 \mathrm{~g} / \mathrm{cc})$, particle density $(1.17 \mathrm{~g} / \mathrm{cc})$ and porosity $(49.82 \%)$ of the MSW compost were within the acceptable limits (Table 3 ).

\subsection{Moisture content}

Moisture content of $25 \%$ provides some advantages of processing or storage conditions and also ease of volume of handling and transport. Moisture content in the compost is desired to have $15-25 \%$ moisture in the finished product. Composts with less moisture contents may not have been fully stabilized or 
may have been stored for long periods leading to moisture loss. While excessively dry composts are often dusty and unpleasant to handle, compost with too high moisture content become too clumpy and increase transportation cost. If the compost is too moist then the air spaces are filled with water limiting the amount of oxygen that the organisms can obtain [26,27]. Moisture is a necessary prerequisite for microbial activity but excessive moisture will reduce porosity and oxygen supply, which will result in an anaerobic decomposition and release of unpleasant odour.

\subsection{Water holding capacity}

Water-holding capacity of the compost was $84 \%$. The water-holding capacity of the compost helps to retain moisture against drainage due to the force of gravity and determines its ability to sustain plant life during dry periods.

\subsection{Bulk and particle density}

The bulk density of compost is defined as its weight per unit volume and The particle density of compost is defined as its weight per unit volume of solid compost. The bulk density of MSW compost was $0.588 \mathrm{~g} / \mathrm{cc}$. and the particle density of the compost was found $1.17 \mathrm{~g} / \mathrm{cc}$. It mea sures how easily air and water can move through a compost pile. Lower value means better flow and higher value means poorer flow. Composts with lower bulk and particle density are desirable as these increases water holding capacity of soil when applied continuously for longer period of time [28].

\subsection{The porosity}

The porosity was calculated to measure the volume of pore space in the compost. It measures the proportion of a given volume of compost occupied by pores containing air and water. The porosity of the MSW compost was $49.82 \%$.

\subsection{Chemical properties}

The chemical properties of the MSW compost have been presented in Table 3.

\subsection{The $\mathbf{p H}$}

$\mathrm{pH}$ is a measure of acidic or alkaline nature of the compost. The $\mathrm{pH}$ value of the MSW compost was 7.3. The preferred range of $\mathrm{pH}$ of the matured compost is 6.5 and 7.5. The $\mathrm{pH}$ of the compost is important, since applying compost to the soil can alter the soil $\mathrm{pH}$ which in turn can affect the availability of nutrients to plants [29]. Microorganisms tend to modify their environment and the products of decomposition may alter pH over time. Near-neutral pH is preferred for most efficient microbial activity. The range of $\mathrm{pH}$ values suitable for bacterial development is 6.0-7.5, while fungi prefer an environment in the range of pH 5.5-8.0. Averagely, mature composts have $\mathrm{pH}$ between 6 and 8 indicating maturity of the compost.

Table 3: Physical and chemical characteristics of the MSW compost

\begin{tabular}{|l|l|l|l|}
\hline Parameter & Value & Nutrient & Value \\
\hline Colour and odour & Brown and earthy smell & Total N (\%) & $0.896 \pm 0.03$ \\
\hline Moisture content (\%) & $25 \pm 1.56$ & $\mathrm{~K}(\%)$ & $0.45 \pm 0.02$ \\
\hline Water holding capacity $(\mathrm{ml} / \mathrm{kg})$ & $840 \pm$ & $\mathrm{P}(\%)$ & $0.30 \pm 0.01$ \\
\hline Bulk density (g/cc) & $0.587 \pm 0.02$ & $\mathrm{~S}(\%)$ & $0.46 \pm 0.02$ \\
\hline Particle density (g/cc) & $1.17 \pm 0.05$ & $\mathrm{Ca}(\mathrm{mg} / \mathrm{kg})$ & $13636 \pm 85.50$ \\
\hline Porosity $(\%)$ & $49.82 \pm 2.60$ & $\mathrm{Fe}(\mathrm{mg} / \mathrm{kg})$ & $8939 \pm 55.5$ \\
\hline $\begin{array}{l}\text { pH } \\
\text { compost }: \text { water }=1: 2.5)\end{array}$ & $7.3 \pm 0.30$ & Mg & $2386.78 \pm 22.15$ \\
\hline EC $(\mathrm{dS} / \mathrm{m})$ & & $(\mathrm{mg} / \mathrm{kg})$ & \\
\hline Organic matter $(\%)$ & $2.60 \pm 0.49$ & & \\
\hline C:N ratio & $22.5 \pm 1.75$ & & \\
\hline
\end{tabular}

\subsection{The electrical conductivity (EC)}

The electrical conductivity of the MSW compost was found $2.4 \mathrm{dS} / \mathrm{m}$. EC is measure of soluble salt content. Undesired salt levels can be harmful to germinating seeds and plants when compost is applied as growing medium. The desired ranges may not apply when compost is used as an amendment because of the diluting effect of mixing the compost with soils. EC reflects the degree of salinity in the composting product, which indicates its possible phytotoxic /phyto-inhibitory effects (e.g. low germination rate, withering) on the growth of plants. A low electric conductivity could be an in dicator of complex nutrients and therefore desirable. The decrease of EC in the composting process is the direct consequence of the increased concentration of nutrients, such as nitrate and nitrite. Due to high initial microbial activity and mineralization, soluble salt content will be high and hence, high EC in initial stages. In later stages, as humiliation proceeds, the humic fractions may become complexes with the soluble salts decreasing the amount of mobile free ions [30].

\subsection{The C:N ratio}

The C:N ratio of the MSW compost was 14.5. The C:N ratio determines the extent of composting and degree of compost maturity. The C:N ratio narrow down as nitrogen remains in the system, while some of the carbon is released as $\mathrm{CO}_{2}$. A C:N ratio of $>25$ likely indicated stable compost. It is a general indicator of whether a compost will rob plant root's nitrogen. The ideal finished compost should have a C:N ratio between 15:1 and 25:1. High C:N ratio ( $>30: 1)$ indicates non stability of the compost and low $\mathrm{C}: \mathrm{N}$ ratio indicates the low organic matter or high $\mathrm{N}$ content in compost. Ideal compost feedstock mixtures should have an initial C: $\mathrm{N}$ ratio of about 30. During the compost process the $\mathrm{C} / \mathrm{N}$ ratio decreases and the rate of decrease is dependent on the ratio in the beginning process and on the composting materials. Maintaining the correct $\mathrm{C}: \mathrm{N}$ ratio is important to obtain good quality compost. The C: $\mathrm{N}$ ratio during composting of municipal solid waste might be narrowed down from 40:1 to 16:1. The C:N ratio should be between 25:1 and 35:1 for most compost organisms to thrive and have a high degree of efficiency of $\mathrm{N}$ assimilation into microbial biomass. When the C:N ratio is too low, $\mathrm{N}$ is lost through ammonia volatilization [31]. A C:N ratio greater than 40:1 promotes immobilization of plant-available nitrogen and slows the decomposition process because of limited $\mathrm{N}$.

\subsection{The organic matter content}

Organic matter is the measure of carbon based materials in the compost. Organic matter is an important ingredient in all soils and has an important role to 
play in maintaining soil structure, nutrient availability and water holding capacity. The organic matter content of the MSW compost was $22.5 \%$. The preferred organic matter content of compost is within 30 to $60 \%$. If the organic matter level is over $60 \%$, then the compost is not yet matured, and it could temporality inhibit plant growth when mixed with soil. If the level of organic matter is low, then the compost simply would not improve the soil well a better-quality product would.

\subsection{Nutrients content}

The nitrogen, phosphorus, potassium and sulphur content the MSW compost were $0.896 \%, 0.30 \%, 0.45 \%$ and $0.46 \%$, respectively. Concentration of nutrients in MSW compost depends on the feed stock used and stage of maturity. The nutrient content of most of the composts is relatively low as compared to most commercial fertilizers. Although composts are relatively low in macronutrients (NPK), they generally are excellent source of micronutrients (Fe, $\mathrm{Zn}, \mathrm{Mn}$ ). They release nutrients slowly and are considered more environmental friendly. The content of S, Ca, $\mathrm{Fe}$ and $\mathrm{Mg}$ were $0.46 \%, 1.33 \%, 0.89 \%$ and $0.24 \%$, respectively. The concentration of $\mathrm{Mn}$ and $\mathrm{Mo}$ in compost were found $281 \mathrm{ppm}$ and $0.40 \mathrm{ppm}$, respectively. The concentration of micronutrients such as $\mathrm{Cu}, \mathrm{Zn}$ and $\mathrm{Si}$ were found 39.68, 141.64 and $174.98 \mathrm{ppm}$, respectively.

\subsection{Heavy metal concentration}

Heavy metal content is considered another important quality parameter necessary for protecting the soil and water resource from pollution.

Table 4: Heavy metals concentrations of the MSW compost

\begin{tabular}{|l|l|l|l|l|}
\hline Heavy metal & $\begin{array}{l}\text { Value } \\
(\mathrm{mg} / \mathrm{kg})\end{array}$ & Heavy metal & $\begin{array}{l}\text { Value } \\
(\mathrm{mg} / \mathrm{kg})\end{array}$ & $\begin{array}{l}\text { Ohai EPA Standards } \\
(\mathrm{mg} / \mathrm{kg})\end{array}$ \\
\hline $\mathrm{Mn}$ & $281.98 \pm 6.85$ & $\mathrm{Cd}$ & $0.39 \pm 0.025$ & 35 \\
\hline $\mathrm{Mo}$ & $0.40 \pm 0.02$ & $\mathrm{As}$ & $2.27 \pm 0.241$ & 41 \\
\hline $\mathrm{Si}$ & $174.98 \pm 4.72$ & $\mathrm{Cu}$ & $39.68 \pm 2.52$ & 1500 \\
\hline $\mathrm{Zn}$ & $141.64 \pm 3.58$ & $\mathrm{~Pb}$ & $48.88 \pm 2.67$ & 300 \\
\hline $\mathrm{Cr}$ & $17.15 \pm 1.38$ & $\mathrm{Hg}$ & trace & 7.8 \\
\hline $\mathrm{Co}$ & $0.61 \pm 0037$ & $\mathrm{Ni}(\mathrm{mg} / \mathrm{kg})$ & $9.01 \pm 0.68$ & 420 \\
\hline
\end{tabular}

Municipal solid wastes contain heavy metals at variable concentrations. The elements boron, zinc, copper, and nickel are essential in small amounts, but in higher amount they may decrease plant growth. Other trace elements like arsenic, cadmium, lead, and mercury are of concern primarily because of their potential to harm soil organisms and animals and human who may eat contaminated plants or soil. The concentration of $\mathrm{Cd}, \mathrm{Co}, \mathrm{As}, \mathrm{Cr}, \mathrm{Cu}$ and $\mathrm{Pb}$ of $\mathrm{MSW}$ compost were $0.39,0.61,2.27,17.15,39.68$, and $48.88 \mathrm{mg} / \mathrm{kg}$ respectively and trace amount $\mathrm{Hg}$ was found and were below the permissible limits of Ohai EPA Standards ( Annexed-1). The heavy metals in MSW composts of Mymensingh city were considerably lower at the critical level and compared to the contents found in the samples from USA and European countries [32].

\subsection{Bacteriological study in compost}

MSW compost samples were tested for the presence of E. coli and Salmonella. The harmful pathogens like Salmonella and Coliform and E. coli were not found in the MSW compost (Table 5). This might be due to that the population of pathogens in MSW compost destroyed during the thermophilic stage due to high temperature. The total number of microbial population in dry compost was measured and the range was 35000 to 90000 per gram compost. When the temperature rises up to $650 \mathrm{C}$ during composting period, these pathogens are usually destroyed as they reach their thermal death point [33]. Total faecal coliforms, and specifically E. coli., faecal Streptococci, Staphylococci, Salmonella and Shigella decrease greatly in numbers in MSW compost after the compost reached temperatures above $55^{\circ} \mathrm{C}[34]$.

Table 5: Microbial Characteristics of compost

\begin{tabular}{|l|l|l|}
\hline \multicolumn{2}{|l|}{ Parameter } & Value \\
\hline 1 & Presence of E. coli & Nil \\
\hline 2 & presence of Salmonella & Nil \\
\hline 3 & Microbial population (number/g air dry compost) & $35000-90000$ \\
\hline
\end{tabular}

\subsection{Conclusion}

In the present study a complete characterization of municipal solid waste compost (MSWC) was done and compared with the standard values before using for soil improvement and plant growth. The maturity tests confirmed that the MSW compost prepared from the solid wastes was matured, stable and good for soil amendment. Physico-chemical analysis of compost from the point of view moisture content, pH, EC, organic matter, calcium, magnesium, total phosphorus, total nitrogen, $\mathrm{C} / \mathrm{N}$ ratio, sodium, potassium agreed with recommended standards The data presented in Tables 1 to 5 showed that MSW compost prepared at the BAU field laboratory, Mymensingh by the solid wastes collected from Mymensingh pourashava was matured and stable, mediumgrade quality and the pathogens E. coli and Salmonella were absent in the compost which can be used as fertilizer or soil amendment without the risk of soluble salts and heavy metal contamination, if the quality is maintained properly.

Annexed 1: Typical ranges of test parameters in quality compost

\begin{tabular}{|l|l|}
\hline Test Parameter & Range \\
\hline $\mathrm{pH}$ & $6.8-7.3$ \\
\hline Soluble salts & $0.35-0.64 \mathrm{dS} \mathrm{m}^{-1}\left(\mathrm{mmhos} \mathrm{cm}^{-1}\right) \quad(1: 5 \mathrm{v} / \mathrm{v}$ method $)$ \\
\hline Nitrogen & $1.0-2.0 \%$ \\
\hline Phosphorus & $0.6-0.9 \%$ \\
\hline potassium & $0.2-0.5 \%$ \\
\hline Moisture content & $45-50 \%$ \\
\hline Organic Matter & $35-45 \%$ \\
\hline Particle size & passes $3 / 8{ }^{\prime \prime}$ screen \\
\hline Bulk density & $900-1,000 \mathrm{lbs} / \mathrm{yd} 3$ \\
\hline
\end{tabular}


Source: Ohio State University fact Sheet; $\underline{\text { http://ohioline.osu.edu/anr-fact/0015.html }}$

\subsection{References}

[1] R.J. Buresh, P.A. Sanchez, and F. Calhour, “Replenishing soil tertility in Africa”, Soil Sci. Soc. Amer. Madism, USA, vol. 51, 1997.

[2] J.W. Doran, and M.R. Zeoiss, "Soil health and sustainability: managing the biotic component of soil quality", Appl. Soil Ecol. Vol. 15, Pp. 3-11, 2000.

[3] Alamgir, “Characterization of MSW and nutrient contents of organic component in Bangladesh”, Vol. 6, No. 4, 2007.

[4] A. Ebid, H., Ueno, A., Ghoneum, and N. Asagi, “Uptake of carbon and nitrogen through rice root from 13C and 15N duel-labaled maize residue compost", Int. J. Biol. Chem., Vol. 1, No. 2, Pp. 75-87, 2007.

[5] M. Sharholy, K. Ahmad, G. Mahmood, and R.C. Trivedi, “Municipal solid waste management in Indian cities - a review”, Waste Management, Vol. 28, Pp. 459-467, 2008.

[6] T. Narayana, "Municipal solid waste management in India: from waste disposal to recovery of resources", Waste Management, Vol. 29, Pp. 1163-1166, 2009.

[7] K.R. Gray, K. Sherman, and A.J. Biddlestone, "A review of composting, Part 1 Microbiology and biochemistry", Process Biochemistry, Vol. 6, No. 6, pp. 3236, 1971.

[8] C. Marugg, M., Gerbus, R.C. Hansen, H.M., Keener, and H.A.J., Hoitink, "A kinetic model of the yard waste composting process", Compost Science Utilization, Vol. 10, Pp. 38-51, 1993.

[9] M.R. Boni, and L. Musmeci, “Organic fraction of municipal solid waste (OFMSW): extent of biodegradation”, Waste management and research, Vol. 16 (2), Pp 103-107, 1998.

[10] G. Eriksen, F. Coale, and G. Bollero, "Soil nitrogen dynamics and maize production in municipal solid waste amended soil”, Agron. J., Vol. 91, Pp. 10091016, 1999.

[11] R. Wolkowski, “Nitrogen management considerations for landspreading municipal solid waste compost”, J. Environ. Qual., Vol. 32, Pp. 1844-1850, 2003.

[12] F. Laura, and D.H. Jodi, "The importance of Soil Organic Matter in Cropping Systems of the Northern Great Plains University of Minnesota”, Extension, 2009.

[13] L. Otten, Wet-dry composting of organic municipal solid waste: current status in Canada. Can. J. Civil Eng., 28 (Suppl. 1), Pp. 124-130, 2001.

[14] M. Zhang, D. Heaney, B. Henriquez, E. Solberg, E. Bittner, "A four year study on influence of biosolids/MSW cocompost application in less productive soils in Alberta: nutrient dynamics", Compost Sci. Util., Vol. 14, No. 1, Pp. 68-80, 2006.

[15] S. Jakobsen, "Aerobic decomposition of organic wastes 2. Value of compost as fertilizer", Resour. Conserv. Recy., Vol. 13, Pp. 57-71, 1995.

[16] C. Crecchio, M. Curci, R. Mininni, P. Ricciuti, and P. Ruggiero, "Short term effects of municipal solid waste compost amendments on soil carbon and nitrogen content, some enzyme activities and genetic diversity”, Biol. Fert. Soils., Vol. 34, Pp. 311-318, 2001.

[17] G. Ranalli, G. Botturea, P. Taddei, M. Garavni, R. Marchetti, and G. Sorlini, "Composting of solid and sludge residues from agricultural and food industries, Bio-indicators of monitoring and compost maturing", Journal of Environmental Science and Health, Vol. 36, No. 4, Pp. 415-436, 2001.

[18] N.M. Trautmann, and M.E. Krasny, Composting in the Classroom. Cornell Waste Management Institute, Cornell University, USA, 1997.

[19] N. Saha, and B. Mandal, “Microbial strategies for crop Improvement”, M, S. Khan et al., (eds.), Springerverlage Berlin Heidelberg, 2009.

[20] C.A. Black, "Methods of Soil Analysis part -1 and part-2", Amer. Sos. Agron.Inc. Madison, Wiscosin, USA, 1995.

[21] R. Kumar, S. Pandey, and A. Pandey, “Plant roots and carbon sequestration”, Current Sci., Vol. 91, No. 7, Pp. 886-890, 2006.

[22] A.L. Page, and D.R. Keeney, “Methods of Soil Analysis, Part 2.”, 2 ${ }^{\text {nd }}$ Ed. Amer, Soc. Agron. Inc. Madison, Wiscosin, U.S.A, 1989.

[23] A.K. Mani, R. Santhi, and K.M. Sellamuthu, "A handbook of laboratory analysis", 1st edition, A.E. Publications No.10. Sundaram, P.N. Pudur, Coimbatore, ISBN 978-81-902558-8-2, pp. 156-167, 2007.

[24] R.E. Buchanan, and N.E. Gibbons, "Bergey's manual of determinative bacteriology, 8th edition”, The Williams and Wilkins Company, Baltimore, Pp 29, 1974.

[25] R.C. Dubey, and D.K. Maheshwari, “Practical Microbiology, 2nd edition”, S. Chand \& Company Ltd., Ram Nagar, New Delhi. Pp. $352,2006$.

[26] A. Maynard, "Cumulative effect of annual additions of MSW compost on the yield of field-grown tomatoes”, Compost Sci. Util., Vol. 3, No. 2., Pp. 47-54, 1995.

[27] Food and Fertilizer Technology Center. Compost Production: a manual for Asian farmers. Taipei 106, Taiwan, 2005.

[28] G. Sarwar, H. Schmeisky, N. Hussain, and S. Muhammad, "Improvement of soil physical and chemical properties with compost application in rice-wheat cropping system", Pak. J. Bot., Vol. 40, No. 1, Pp. 275-282, 2008.

[29] C.F. Tester, "Organic amendment effects on physical and chemical properties of a sandy soil”, Soil Sci. Soc. Am. J. Vol. 65, Pp. 1284-1292, 1990.

[30] S. Ghosh, B. Wilson, S.K. Ghoshal, N. Senapati, and Mandal, Biswapati. Management of soilquality and carbon sequestration with long-term application of organic amendments. $1^{\text {th }}$ World Congres Soil Sci. 1-6 August,2010. Brisbane, Australia. 
[31] S. Ghosh, B. Wilson, B. Mandal, S.K. Ghoshal, and I. Growns, “Changes in soil organic carbon pool in three long-term fertility experiments with different cropping systems, inorganic and organic soil amendments in the eastern cereal belt of India", Australian J. Soil Res, 2009.

[32] X. He, S. Traina, and T. Logan, “Chemical properties of municipal solid waste compost”, J. Environ. Qual., Vol. 21, Pp. 318-329, 1992.

[33] J.D.G. Kirk, “Rice root properties for internal aeration and efficient nutrient acquisition in submerged soil”, New Phytologist, Vol. 159, Pp. 185-195, 2003.

[34] A. Hassen, K. Belguith, N. Jedidi, A. Cherif, M. Cherif, and A. Boudabous, "Microbial characterization during composting of municipal solid waste", Bioresour. Technol., Vol. 80, Pp. 217-225, 2001. 